\title{
Organic Amendments for Landscape Soils
}

JIM DOWNER, UC

Cooperative Extension

Advisor for environmental

horticulture and plant

pathology in Ventura

County

BEN FABER, UC

Cooperative Extension

Advisor for water, soils, and

subtropical crops in Ventura

County
$\Lambda$

mending is the addition of

materials (organic or inorganic)

to soil. Amendments are tilled, dug, or

otherwise incorporated to modify a soil

in the zone where roots will grow-

unlike mulches, which are applied to the undisturbed soil surface. Organic amendments may be incorporated into landscape soils to improve plant growth. However, research has not shown that adding amendments to planting holes for perennial plants provides a significant advantage compared to using native backfill (Harris 1992; Hodel et al. 2006).

It is not hard to imagine some soils (principally sands) where amendments would provide a slight boost, but most studies on perennial plants have focused on loamy or clay soils. There are several reasons that amendments might not provide an advantage for perennial plants. For example, perennial roots do not reside in the planting hole for long, so amendments can only be effective for a short time. Since amending can harm some large perennial plants if done incorrectly, the University of California does not generally recommend the practice. Harris (1992) does not recommend amending for trees, shrubs, or vines, and amending was not seen to have any effect on transplanted palms in Hodel et al. (2006). Most professionals restrict the use of amendments for annual plant beds.
The reason often given for amending is that the soil is "poor." While many gardeners or professionals may take a dim view of unamended soil quality, most soils allow for adequate plant growth. However, many soils, especially in Southern California, are low in organic matter. In such cases, adding organic matter has many potential benefits (Cooperband 2002). The benefits and detriments of amending depend on the quantity and quality of the amendments and how they are incorporated. The potential benefits include rapid (immediate) physical modification of the planting bed; increased moisture-holding capacity in the soil; an increase in nutrients and nutrient-holding capacity (the soil's cation exchange capacity, or CEC); improved soil porosity and aggregate formation, which improve drainage and aeration; rapid increase in soil organic matter and microbial activity; and suppression of soilborne pathogens. The potential detriments of amending include nutrient draw from the soil (nitrogen immobilization); toxicity from residual phytochemicals; addition of pests (weeds or root pathogens); damage to or destruction of soil structure; harm to the soil food web; increased soil salinity; and addition of contaminants such as plastics to gardens.

\section{WHEN TO AMEND}

Amendments typically benefit soils such as sands and sandy loams, which have comparatively low organic matter contents, by increasing water and nutrient-holding capacity. Clay soils may also benefit from amendments because added organic matter can disperse clay particles, reduce the amount of shrinkage on drying, and increase infiltration rates. 
Amended clays are easier to work and plant in, and weeds are more easily extracted. The addition of organic matter allows some soils to retain nutrients longer, reducing the need to add nutrients (fertilizer). However, because organic matter can break down rapidly in soil, the potential benefits can disappear over a period of months-depending on the carbon-to-nitrogen ratio of the amendment.

According to Harris (1992), a 50:50 amendment-to-soil mix is the minimal amending rate. For perennials, a large area must be amended, not just the backfill in the planting hole. Amending holes for planting trees is not recommended because it has little effect on subsequent growth and in some cases can have a detrimental effect on plant growth.

Amending soil requires disturbing it by digging, rototilling, turning with a shovel, spade, or plow, or some other kind of incorporation process. Mixing amendment in a site's soil destroys soil structure and disrupts the soil food web. Beneficial nematodes are highly sensitive to tillage and many are killed in the process, often perturbing the entire soil food web (Ferris and Matute 2003). Unlike mulching, amending immediately changes physical, chemical, and biological qualities of soil.

Amending can also introduce pathogens, salts, toxic phytochemicals, or weeds to landscapes and gardens, depending on the amendment used. Soils are fragile, so structure destroyed by amending can take years to recover. The need for further amending should be considered carefully at each planting time.

\section{EVALUATING SOIL AMENDMENTS}

Unlike mulching (the process of laying organic matter on the soil surface), amending can perturb soil so rapidly that it may not be suitable for plant growth. Undecomposed substrates such as wood chips are high in carbon and low in nitrogen. High carbon-to-nitrogen amendments cause the microbial community in soil to attack the carbon and utilize all the free nitrogen in the soil. This can result in nitrogen immobilization in the soil and plant deficiencies if plants are immediately planted in the amended soil. Wood-containing amendments tend to persist in soil, since lignin is slowly broken down by fungi.

Useful amendments have fine particles, are composted, and are low in salts-but have enough nitrogen to supply both plants and microbes in soil. If amendments that have coarse particles are applied at rates of 50 percent by volume, the soil may require continued additional nitrogen over time. Screened or fine materials have greater surface area than course particles and impart greater water-absorbing and nutrient-exchanging properties to soil. Well-composted substrates should be free of pathogens and other pests.

Composts made from plant and manure feedstocks tend to have higher concentrations of plant-required nutrients than yard waste (compost composed of municipally recycled yard clippings). Since composts lose about two-thirds of their carbon and moisture during the decomposition process, they have a much higher mineral content than their feedstock. Organic matter in manures has been digested by animals, and additional composting further increases salt levels, sometimes to plant-damaging levels. Composted manures do not reside long in soils, and their organic matter inputs are short-term. Manures should be used with care, or in lower quantities, as they can damage sensitive plants. Some manures and composts can be contaminated, since some long-term soil-residual herbicides, such as clopyralid, are not broken down during digestion or in the composting process.

There are many sources of soil amendments-a few are listed in table 1. Some amendments are composts; some are plant products that are not composted. Composts usually persist longer in soil because they have already undergone decomposition and have a higher percentage of recalcitrant organic matter. Peat moss has been the gold-standard amendment for many gardens (fig. 1). Peat moss is harvested from peat bog plant communities and these habitats are easily destroyed, so the sustainability of peat moss use is questionable. Coco fiber, or coir, is also a good amendment, but can have high salt content, depending on how it is processed. Biosolids are excellent amendments and often produce 
Table 1. Amendment qualities

\begin{tabular}{|c|c|c|c|c|}
\hline Amendment & Benefits & Detriments & Other Uses & Notes \\
\hline Biosolids composts & $\begin{array}{l}\text { - contains more nitrogen than } \\
\text { most amendments } \\
\text { - stimulates growth }\end{array}$ & $\begin{array}{l}\text { - may be contaminated } \\
\text { with metals }\end{array}$ & - & $\begin{array}{l}\text { Biosolids are made from } \\
\text { treated human waste. }\end{array}$ \\
\hline $\begin{array}{l}\text { Coir or other coconut } \\
\text { fiber products }\end{array}$ & $\begin{array}{l}\text { - can be an alternative to peat } \\
\text { moss }\end{array}$ & $\begin{array}{l}\text { - expensive } \\
\text { - many be high in sodium } \\
\text { - may require leaching }\end{array}$ & $\begin{array}{l}\text { - mostly as a container } \\
\text { medium }\end{array}$ & $\begin{array}{l}\text { Use of coir as a soil } \\
\text { amendment needs } \\
\text { further research. }\end{array}$ \\
\hline Coffee grounds & - acidic, finely ground & $\begin{array}{l}\text { - may contain toxic } \\
\text { compounds for plants } \\
\text { - grounds vary by source } \\
\text { - persistent in soil } \\
\text { - contain nitrogen }\end{array}$ & $\begin{array}{l}\text { good choice for } \\
\text { increasing porosity of } \\
\text { heavy (clay) soils }\end{array}$ & $\begin{array}{l}\text { Test a small area to see } \\
\text { if the grounds you are } \\
\text { using are toxic (see } \\
\text { article text). }\end{array}$ \\
\hline Crop residues & $\begin{array}{l}\text { - increase soil microbial activity } \\
\text { - increase soil organic matter }\end{array}$ & $\begin{array}{l}\text { - quickly break down if } \\
\text { material is fresh }\end{array}$ & - often used in agriculture & $\begin{array}{l}\text { Rototilling previous } \\
\text { crops into soil increases } \\
\text { soil organic matter. }\end{array}$ \\
\hline Horse manure & $\begin{array}{l}\text { - adds low amounts of nutrients } \\
\text { - less saline than steer manure } \\
\text { - high organic matter }\end{array}$ & $\begin{array}{l}\text { - may contain herbicide } \\
\text { residues } \\
\text { - may immobilize nitrogen } \\
\text { if used in large quantities } \\
\text { - possible weed seeds }\end{array}$ & - & $\begin{array}{l}\text { Manure is best used } \\
\text { when composted. } \\
\text { Composted manures } \\
\text { may be high in salts } \\
\text { and should be applied } \\
\text { carefully-that is, not } \\
\text { too much should be } \\
\text { applied until potential } \\
\text { plant damage can be } \\
\text { assessed. }\end{array}$ \\
\hline Mushroom compost & $\begin{array}{l}\text { - contains more nutrients than } \\
\text { some manures } \\
\text { - increases organic matter and } \\
\text { CEC }\end{array}$ & $\begin{array}{l}\text { - not persistent } \\
\text { - can be quite saline } \\
\text { - not commonly available }\end{array}$ & $\begin{array}{l}\text { may be a component of } \\
\text { container media }\end{array}$ & - \\
\hline Peat moss & $\begin{array}{l}\text { - fine texture } \\
\text { - stable, will not easily break } \\
\text { down } \\
\text { - low pH } \\
\text { - high CEC } \\
\text { - persists through more than } \\
\text { one growing cycle in soil } \\
\text { - sphagnum peat can be farmed }\end{array}$ & $\begin{array}{l}\text { - may be hydrophobic } \\
\text { - peat bog harvest may } \\
\text { not be environmentally } \\
\text { sustainable }\end{array}$ & $\begin{array}{l}\text { container media and } \\
\text { in high-value color } \\
\text { beds where peak } \\
\text { plant performance is } \\
\text { necessary }\end{array}$ & $\begin{array}{l}\text { Peat moss is one of } \\
\text { the most expensive } \\
\text { amendments. }\end{array}$ \\
\hline $\begin{array}{l}\text { Steer manure } \\
\text { compost }\end{array}$ & $\begin{array}{l}\text { - adds nitrogen and other } \\
\text { elements }\end{array}$ & $\begin{array}{l}\text { - breaks down rapidly } \\
\text { - may contain excess salts } \\
\text { - may be alkaline-forming } \\
\text { in soil reaction }\end{array}$ & $\begin{array}{l}\text { best used as a seed } \\
\text { topdressing for } \\
\text { turfgrasses }\end{array}$ & $\begin{array}{l}\text { - Leaching is often } \\
\text { required to remove salts. }\end{array}$ \\
\hline Yard waste compost & $\begin{array}{l}\text { - has a high wood content, so is } \\
\text { persistent }\end{array}$ & $\begin{array}{l}\text { - coarse unless screened } \\
\text { - often contains trash } \\
\text { - may be contaminated } \\
\text { with weeds or plant } \\
\text { pathogens } \\
\text { - may be partially } \\
\text { composted } \\
\text { - low C: N ratio } \\
\text { - requires addition of } \\
\text { nitrogen to the soil }\end{array}$ & $\begin{array}{l}\text { - Yard waste is mostly } \\
\text { used as mulch. }\end{array}$ & $\begin{array}{l}\text { Sources may be from } \\
\text { stockpiles or composting } \\
\text { operations. Stockpiles do } \\
\text { not kill all pests. }\end{array}$ \\
\hline Redwood compost & - persistent & $\begin{array}{l}\text { - low } \mathrm{C}: \mathrm{N} \text { ratio, needs to } \\
\text { be nitrified }\end{array}$ & - & - \\
\hline
\end{tabular}




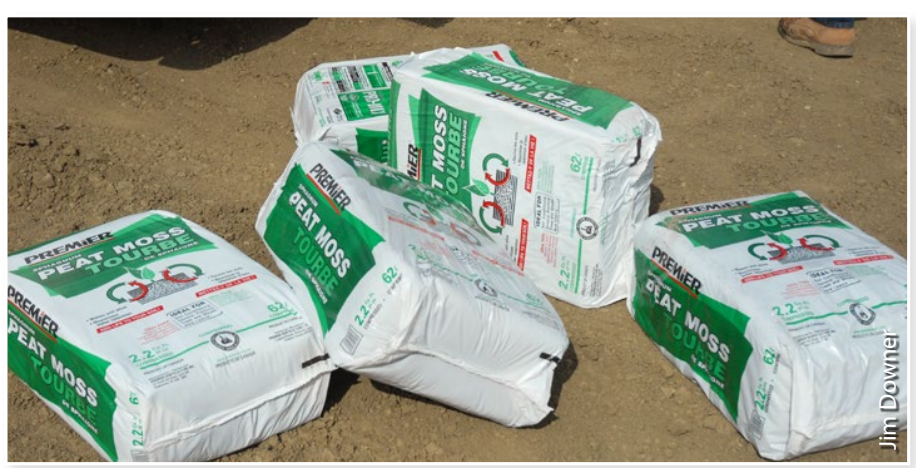

Figure 1. Considered by many to be the gold standard for amendments, peat moss can help reduce soil pH.

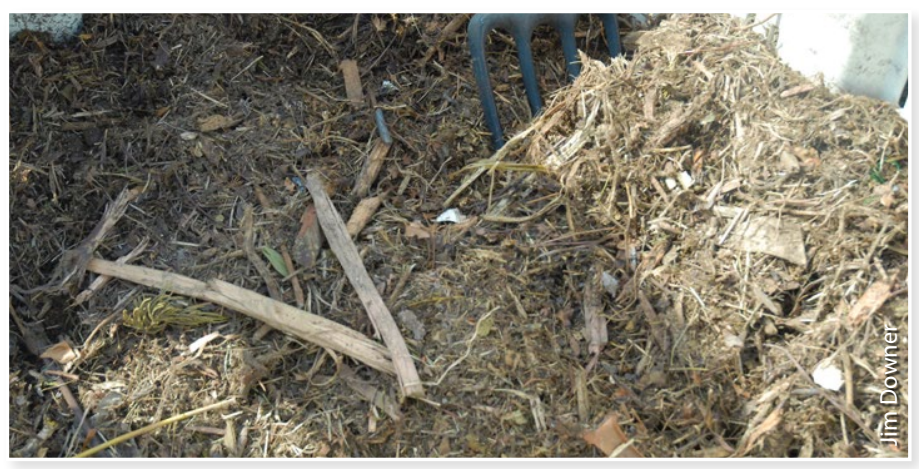

Figure 2. Fresh commercial yard waste is often too coarse and high in carbon to be a useful amendment.

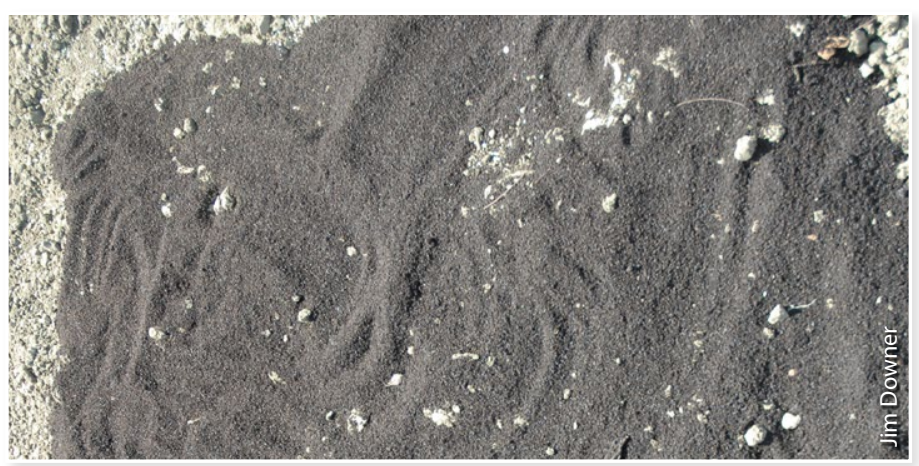

Figure 3. Coffee grounds are increasingly available for use as an amendment. They are acidic and have a fine grind suitable for incorporation.

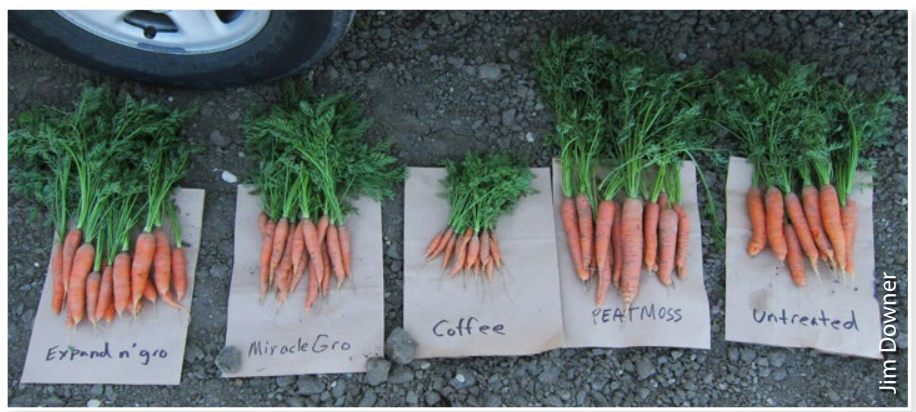

Figure 4. Some coffee grounds limit plant growth, as in the carrots in the center of the image. growth responses, but can contain metals and other biological contaminants.

Homemade compost can be a good amendment because its contents are known. As long as it is properly prepared and cured, it can function very well. Green waste or yard waste compost (fig. 2) can be a good choice for an amendment, but good-quality compost must be mature (that is, it no longer heats up when turned or piled). Composts shouldn't have large chunks of parent material (leaves, sticks, and so on) still visible in the mix. These are signs of a poorly prepared, unfinished, or immature compost.

Many gardeners amend soil with coffee grounds, and with the advent of large coffee companies, spent grounds (which may or may not be composted) may be available in bulk quantities (fig. 3). Be careful, though, as some sources of spent coffee grounds are toxic to many plants, and their use should be limited in any amending situation (fig. 4) (Hardgrove and Livesley 2016). Coffee grounds can contain chemicals that inhibit plant growth. As with all toxic substances, "the dose makes the poison." Small quantities of coffee grounds will pose no harm but at high amending rates by volume (50\% or more), some plants may grow poorly in soils amended with spent coffee grounds.

\section{WEED CONTROL}

Adding amendments to soil can decrease the number of weeds that germinate after amending. In a study on acidic amendments (Downer et al. 2008), we found that pine needles, coffee grounds, and ground lemons led to significantly decreased weed emergence compared to untreated soil and soils amended with peat moss, yard waste, or oak leaves (fig. 5). Reductions in weed seed germination could be due to dilution of the weed seed bank with seed-free amendments or to the presence of phytochemicals in the amendment that are toxic to germinating seeds. However, in turning soil, weed seed that is buried can be brought to the surface and seeds can initiate germination once they are exposed to sunlight. 


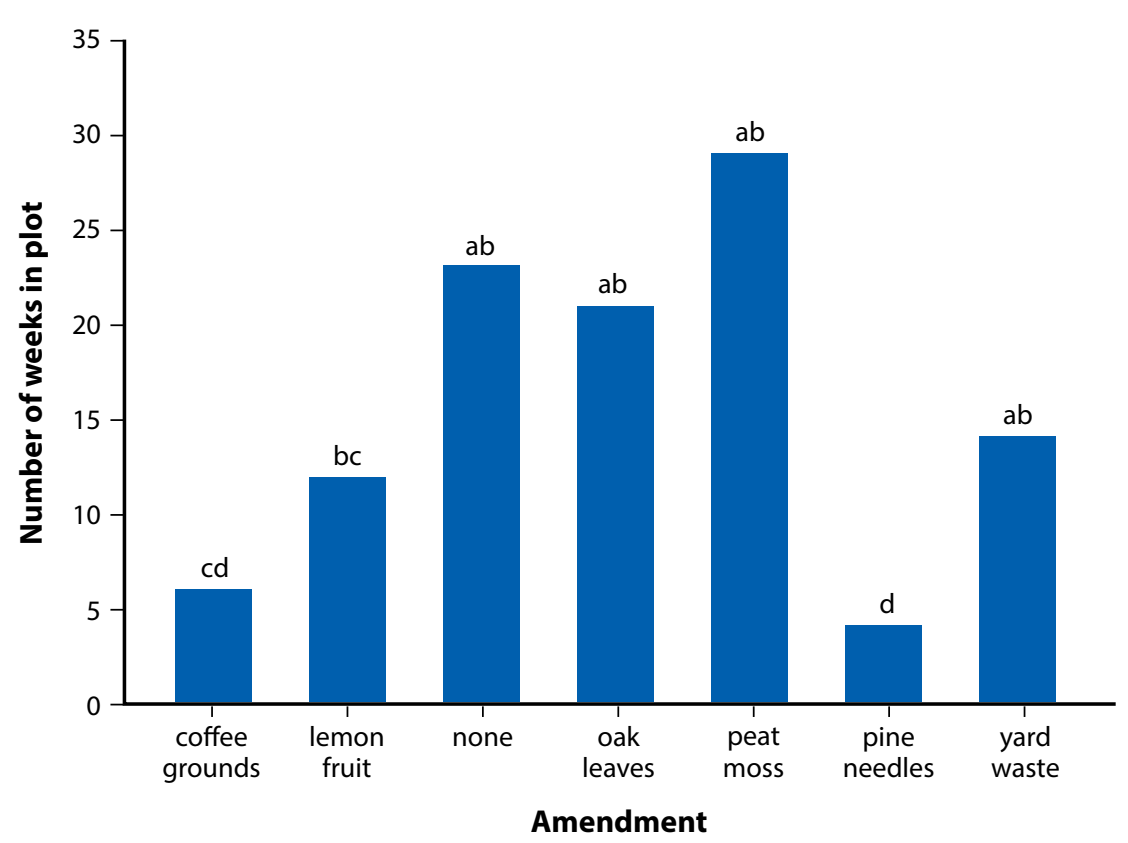

Figure 5. Weed emergence with various amendments ( $25 \%$ by volume of soil). Weed counts for bars marked with the same letter are not significantly different from each other; weed counts for bars marked with different letters are significantly different.

\section{REFERENCES}

Chaney, D. E., L. E. Drinkwater, and G. S. Pettygrove. 1992. Organic soil amendments and fertilizers. Oakland: UC Agriculture and Natural Resources Publication 21505.

Cooperband, L. 2002. Building soil organic matter with organic amendments-A resource for urban and rural gardeners, small farmers, turfgrass managers and large-scale producers. Madison: Center for Integrated Agricultural Systems, University of Wisconsin-Madison.

Downer, A. J., B. Faber, M. Mochizuki, and D. Holstedge. 2008. Soil $\mathrm{pH}$ reduction with sulfur amendments and a cover crop. HortScience 43(4):1234.

Ferris, H., and M. M. Matute. 2003. Structural and functional succession in the nematode fauna of a soil food web. Applied Soil Ecology 23:93-110. https://doi.org/10.1016/S09291393(03)00044-1

Handreck, K. A., and N. D. Black. 2002. Growing media for ornamental plants and turf. Sydney: UNSW Press.

Hardgrove, S. J., and S. J. Livesley. 2016. Applying spent coffee grounds directly to urban agriculture soils greatly reduces plant growth. Urban Forestry \& Urban Greening 18:1-8. https://doi.org/10.1016/j.ufug.2016.02.015

Harris, R. W. 1992. Arboriculture: Integrated management of landscape trees, shrubs and vines. 2nd ed. Englewood Cliffs, NJ: PrenticeHall International.

Hodel, D. R., A. J. Downer, D. R. Pittenger, and P. J. Beaudoin. 2006. Effect of amended backfill soils when planting five species of palms. HortTechnology 16:457-460. https://doi. org/10.21273/HORTTECH.16.3.0457

\section{RATE OF AMENDMENT APPLICATION}

Unlike mulching (mulches can be reapplied at any time), amending should only occur oncebefore planting. However, multiple annual crops of vegetables or flowers can occur in a single year. Organic matter is decomposed by the soil microbial community rapidly because tilling accelerates microbial activity and amending occurs during the growing season, when warm soil temperatures favor breakdown of organic matter. Gardeners can amend when replanting annual planting beds-or, for herbaceous perennials, can do so once, in a larger volume of soil surrounding the planting holes. 
To order or obtain UC ANR publications and other products, visit the UC ANR online catalog at https://anrcatalog.ucanr. edu/ or phone 1-800-994-8849. Direct inquiries to

UC Agriculture and Natural Resources Publishing 2801 Second Street

Davis, CA 95618

Telephone 1-800-994-8849

E-mail: anrcatalog@ucanr.edu

(2021 The Regents of the University of California. This work is licensed under the Creative Commons AttributionNonCommercial-NoDerivatives 4.0 International License. To view a copy of this license, visit https://creativecommons.org/ licenses/by-nc-nd/4.0/ or send a letter to Creative Commons, PO Box 1866, Mountain View, CA 94042, USA.

Publication 8711

ISBN-13: 978-1-62711-190-4

The University of California, Division of Agriculture and Natural Resources (UC ANR) prohibits discrimination against or harassment of any person in any of its programs or activities on the basis of race, color, national origin, religion, sex, gender gender expression, gender identity, pregnancy (which includes pregnancy, childbirth, and medical conditions related to pregnancy or childbirth), physical or mental disability, medical condition (cancer-related or genetic characteristics), genetic information (including family medical history), ancestry, marital status, age, sexual orientation, citizenship, status as a protected veteran or service in the uniformed services (as defined by the Uniformed Services Employment and Reemployment Rights Act of 1994 [USERRA]), as well as state military and naval service.
UC ANR policy prohibits retaliation against any employee or person in any of its programs or activities for bringing a complaint of discrimination or harassment. UC ANR policy also prohibits retaliation against a person who assists someone with a complaint of discrimination or harassment, or participates in any manner in an investigation or resolution of a complaint of discrimination or harassment. Retaliation includes threats, intimidation, reprisals, and/or adverse actions related to any of its programs or activities.

UC ANR is an Equal Opportunity/Affirmative Action Employer. All qualified applicants will receive consideration for employment and/or participation in any of its programs or activities without regard to race, color, religion, sex, national origin, disability, age or protected veteran status.

University policy is intended to be consistent with the provisions of applicable State and Federal laws.

Inquiries regarding the University's equal employment opportunity policies may be directed to: Affirmative Action Compliance and Title IX Officer, University of California, Agriculture and Natural Resources, 2801 Second Street, Davis, CA 95618, (530) 750-1343. Email: titleixdiscrimination@ ucanr.edu. Website: https://ucanr.edu/sites/anrstaff/Diversity/ Affirmative_Action/

An electronic copy of this publication can be found at the UC ANR catalog website, http://anrcatalog.ucanr.edu/.

UC. This publication has been anonymously peer PEER reviewed for technical accuracy by University REVIEWED of California scientists and other qualified professionals. This review process was managed by UC ANR Associate Editor for environmental horticulture, arboriculture, and sustainable landscapes Janet S. Hartin.

web-3/21-LC/SO 